\title{
Proof-of-Concept Simulasi Kadar Saturasi Oksigen untuk Evaluasi Pulse Oximeter
}

\author{
FUAD UGHI \\ Biomedical Engineering Swiss German University \\ Email: fuad.ughi@sgu.ac.id
}

Received 28 Oktober 2017 | Revised 21 Desember 2017 | Accepted 28 Januari 2018

\begin{abstract}
ABSTRAK
Simulator $\mathrm{SpO}_{2}$ yang mengemulasikan sinyal yang ekuivalen dengan saturasi oksigen pada manusia, dapat digunakan untuk evaluasi repeatibility pulse oximeter. Simulator ini tersedia di pasaran dengan harga yang cukup mahal di Indonesia, di kisaran 80-100 juta rupiah. Studi ini bertujuan untuk mengembangkan simulator SpO2 dengan biaya rendah, menggunakan komponen elektronika umum yang ada di pasaran. Karakteristik simulasi mengacu kepada referensi yang diambil dari simulator komersial dengan menggunakan sistem akuisisi data berbasis LabVIEW. Kadar saturasi oksigen disimulasikan dengan mengatur intensitas cahaya light emitting diode (LED), untuk meniru penyerapan cahaya oleh darah pada pembuluh arteri. Digital to analog converter digunakan sebagai LED driver, untuk mengatur besar tegangan ke LED yang berbanding lurus dengan intensitas cahaya. Sebagai pembuktian konsep, studi ini berhasil menyimulasikan kadar saturasi oksigen 80\% dengan galat mencapai 11.25\%, dan 80 denyut jantung per menit dengan galat 6.25\%. Hasil simulasi belum bisa dibandingkan dengan simulator komersial, karena hasil yang belum stabil. Total biaya untuk komponen perangkat keras, mencapai satu juta rupiah.
\end{abstract}

Kata kunci: simulator, saturasi oksigen, pulse oximeter, digital to analog converter, light emitting diode

\begin{abstract}
$\mathrm{SpO}_{2}$ simulator, which emulates signal that equivalent to oxygen saturation level of human, can be used to evaluate repeatibility of pulse oximeter. $\mathrm{SpO}_{2}$ simulators are available in Indonesia, but the price is quite expensive, in range of 80-100 million rupiah. The study aims to develop low-cost SpO simulator, using common electronic components. Characteristic of simulation refer to reference data, which taken from commercial simulator using LabVIEW based data acquisition system. Level of oxygen saturation is simulated by adjusting beam intensity of light emitting diode (LED), to imitate light absorbance by arterial blood. Digital to analog converter is used as $L E D$ driver, to control voltage to $L E D$ that directly proportional to light intensity. As a proof of concept, $\mathrm{SpO}_{2}$ simulation has been successfully performed at level $80 \%$ with error reaches $11.25 \%$ deviation, and heart rate 80 beat per minute with error reaches $6.25 \%$. The simulation result had not compared yet to a commercial simulator, due to the unstable result. Total cost for hardware components of the prototype is around one million rupiah.
\end{abstract}

Keywords: simulator, oxygen saturation, pulse oximeter, digital to analog converter, light emitting diode 


\section{PENDAHULUAN}

Data parameter kesehatan tubuh manusia cenderung fluktuatif, sehingga untuk instrumen pengukuran kesehatan tubuh, menggunakan data parameter kesehatan dari tubuh manusia sebagai nilai standar tidaklah memungkinkan. Beberapa instrumen pengukuran kesehatan dengan relatif mudah dapat menggunakan referensi lain yang berkaitan dengan parameter yang diukur. Hasil pengukuran termometer suhu tubuh dapat dibandingkan dengan sebuah alat ukur suhu yang dianggap terstandar. Kalibrasi tensimeter manual dapat dilakukan dengan mengukur tekanan pada manset dan dibandingkan dengan sebuah alat ukur tekanan yang dianggap terstandar. Tetapi untuk instrumen pengukuran parameter vital kesehatan tubuh manusia seperti tensimeter otomatis, pulse oximeter, dan elektrokardiograf (EKG) akan sulit untuk membandingkan hasil pengukuran dengan sebuah alat ukur terstandar, karena data yang diukur bukanlah data statis besaran baku dalam sistem internasional. Data yang diukur merupakan perbandingan dari sebuah perubahan dari besaran pokok. Oleh karena itu diperlukan simulator untuk tiap parameter vital kesehatan tubuh yang mereplika karakteristik parameter-parameter tersebut sebagai referensi nilai standar.

Salah satu instrumen pengukuran parameter vital adalah pulse oximeter, yang digunakan untuk mengukur kadar saturasi oksigen dalam darah. Kadar saturasi oksigen dalam darah merupakan indikator penyebaran oksigen dalam tubuh manusia dan mengindikasikan jumlahnya mencukupi atau tidak untuk seluruh tubuh, terutama paru-paru (Konica Minolta Sensing, Inc., 2006). Terapi oksigen terkadang dibutuhkan jika kondisi kesehatan seseorang menyebabkan kurangnya kadar oksigen dalam tubuh (Hadiyoso dkk, 2015).

Oksigen terikat pada hemoglobin di sel darah merah ketika bergerak melalui paru-paru, lalu disalurkan ke seluruh tubuh melalui pembuluh darah arteri. Hemoglobin yang mengikat oksigen disebut oksihemoglobin $\left(\mathrm{HbO}_{2}\right)$. Hemoglobin yang tidak mengikat oksigen disebut deoksihemoglobin $(\mathrm{Hb})$. Kadar saturasi oksigen dalam darah arteri $\left(\mathrm{SaO}_{2}\right.$ - arterial blood oxygen saturation) menunjukkan persentase jumlah $\mathrm{HbO}_{2}$ terhadap jumlah hemoglobin dalam darah (Konica Minolta Sensing, Inc., 2006).

$\mathrm{SpO}_{2}$ (percutaneous oxygen saturation) merupakan nilai estimasi dari nilai $\mathrm{SaO}_{2}$ dengan metode pengukuran non-invasif (Withings, n.d.). Pulse oximetry merupakan salah satu metode pengukuran non-invasif untuk pengukuran $\mathrm{SpO}_{2}$. Instrumen pengukurannya disebut pulse oximeter. $\mathrm{HbO}_{2}$ memiliki warna merah terang, sedangkan $\mathrm{Hb}$ memiliki warna merah gelap. $\mathrm{HbO}_{2}$ menyerap lebih banyak cahaya inframerah, sedangkan $\mathrm{Hb}$ lebih banyak menyerap cahaya merah (Konica Minolta Sensing, Inc., 2006). Nama pulse oximeter diambil dari bentuk gelombang yang terbentuk dari cahaya yang dimodulasi oleh denyut arteri (Stubán \& Masatsugu, 2008).

Pulse oximeter memberikan cahaya LED (light emitting diode) merah dan inframerah yang dilewatkan melalui bagian tubuh tertentu, kemudian diterima oleh sebuah sensor cahaya. Persentase saturasi oksigen dikalkulasi dengan mengukur rasio cahaya inframerah dan cahaya merah yang terdeteksi oleh sensor cahaya (Konica Minolta Sensing, Inc., 2006).

Sebagian besar pulse oximeter berfungsi di titik-titik ekstrem tubuh, seperti jari tangan, jari kaki, dan daun telinga. Sebagian besar cahaya terserap oleh jaringan tubuh, tulang dan darah pada vena, tetapi jumlah jaringan tubuh, tulang, dan darah pada vena tidak berubah secara signifikan dalam kurun waktu yang singkat (Philips Medical System, 2002).

Gambar 1 menunjukkan ilustrasi pulse oximeter. 


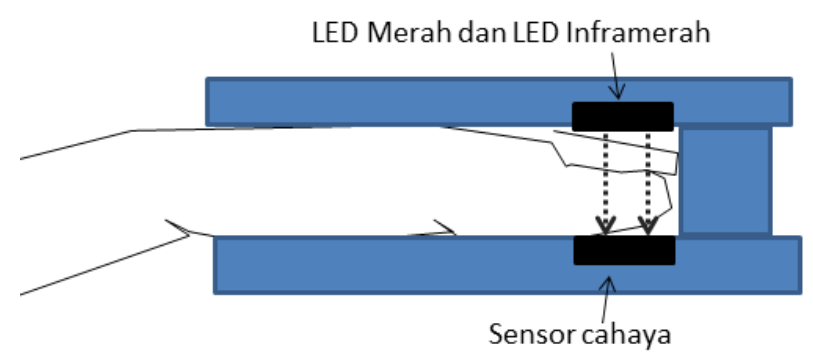

Gambar 1. Ilustrasi Pulse Oximeter

Jumlah darah dalam arteri berubah dalam waktu yang relatif singkat dikarenakan denyut jantung, walapun sebenarnya terdapat nilai konstan pada jumlah darah dalam arteri. Karena biasanya hanya darah dalam arteri yang merupakan komponen penyerap cahaya yang mengalami perubahan volume dalam waktu relatif singkat, maka nilai penyerapan cahayanya dapat dipisahkan dari komponen yang lain (Philips Medical System, 2002).

Gambar 2 menunjukkan karakteristik penyerapan cahaya dari pulse oximeter oleh tubuh. Pulsa yang terbentuk karena modulasi oleh denyut arteri yang menjadi dasar penentuan nilai saturasi oksigen. Nilai amplitudo maksimum dan minimum gelombang yang terbentuk oleh penyerapan cahaya merah dan inframerah, akan digunakan untuk menentukan nilai $R$ rate yang merupakan turunan dari hukum Lambert-Beer (Stubán \& Masatsugu, 2008).

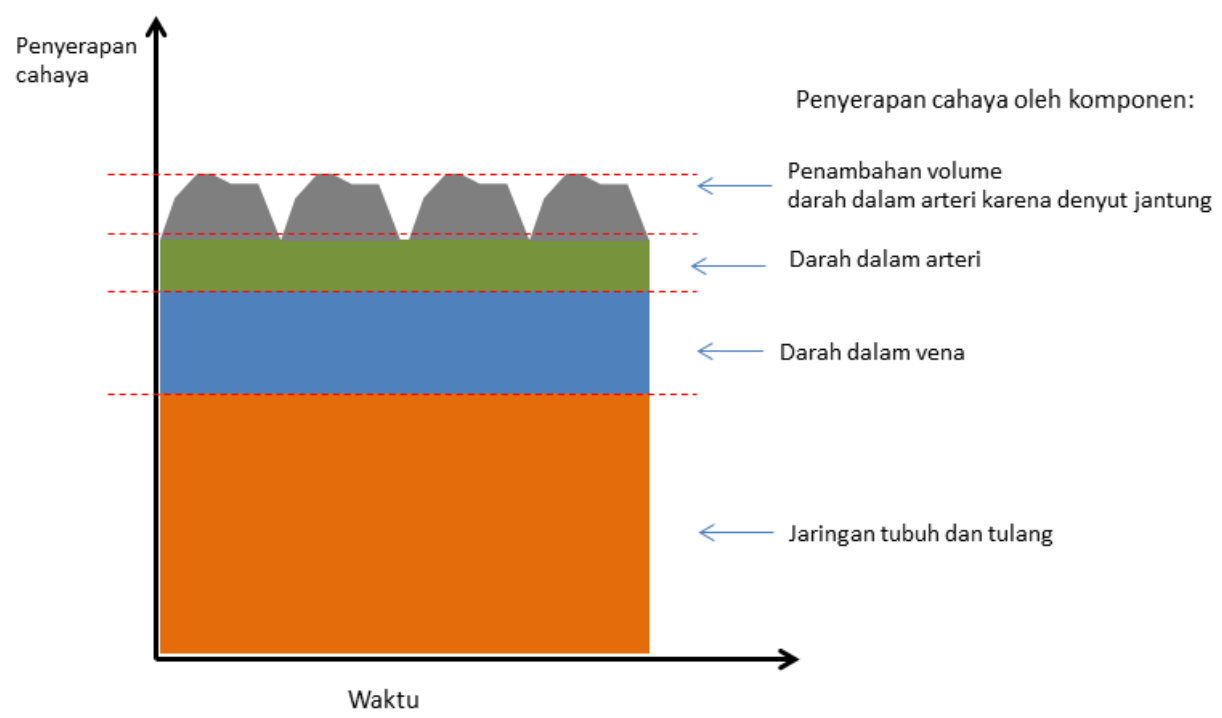

Gambar 2. Karakteristik Penyerapan Cahaya

Satu-satunya data referensi primer untuk saturasi oksigen yang dapat diterima adalah hasil pengujian in vivo pada manusia. Pada sebuah pengujian desaturasi terkontrol, para subjek relawan menghirup secara berurutan campuran gas dengan kadar oksigen menurun dan terhubung ke instrumen monitoring. Sampel darah dari arteri kemudian diambil dan nilai saturasi diukur menggunakan co-oximeter di laboratorium klinis (McMahon, 2013).

Simulator atau tester $\mathrm{SpO}_{2}$ merupakan standar sekunder, yang memberikan nilai ekuivalen dari sebuah alat sebelumnya yang telah divalidasi. Simulator $\mathrm{SpO}_{2}$ digunakan untuk menyimulasikan perubahan intensitas cahaya yang disebabkan oleh penyerapan cahaya oleh darah (Zhang et al., 2013). Kata simulasi bermakna memberikan sebuah nilai palsu yang ekuivalen dari sebuah objek. Sedangkan kata emulasi bermakna mencoba untuk meniru. 
Tester $\mathrm{SpO}_{2}$ lebih tepatnya sebenarnya merupakan emulator, instrumen tersebut hanya memperkirakan kondisi fisiologis dari manusia (McMahon, 2013).

Semua tester pulse oximeter yang ada di pasaran menggunakan antarmuka elektronik atau optikal untuk terhubung ke instrumen yang diuji. Elektronik tester memberi sinyal elektrik ke monitor pulse oximeter melalui kabel sensor, tanpa keterlibatan dari sensor itu sendiri. Optikal tester menyediakan jari artifisial yang terdiri dari elemen mekanik dan/atau optoelektronik yang memungkinkan transmisi yang variatif dari dua jenis cahaya, merah dan inframerah (McMahon, 2013).

Merrick dan Haas (1994) menggunakan sensor cahaya untuk membaca nilai cahaya merah dan inframerah dari pulse oximeter untuk kemudian dimodulasi dengan nilai kadar saturasi oksigen yang ingin disimulasikan. Hasil modulasi kemudian digunakan untuk mengatur cahaya merah dan inframerah dari simulator untuk diberikan pada sensor cahaya pulse oximeter, sehingga seakan pulse oximeter membaca cahaya yang telah melewati jaringan tubuh.

Di pasaran telah tersedia simulator parameter vital kesehatan tubuh tetapi harganya relatif mahal. Mengacu pada daftar e-katalog yang merupakan bagian dari sistem pengadaan barang milik pemerintah Republik Indonesia, harga simulator kadar oksigen mencapai kisaran 100 juta rupiah.

Studi ini bertujuan untuk mengembangkan purwarupa simulator $\mathrm{SpO}_{2}$ berbasis metode optikal dengan biaya lebih murah dibandingkan dengan produk komersial yang telah tersedia, dan menggunakan komponen yang mudah ditemui di pasaran di Indonesia. Walaupun simulator $\mathrm{SpO}_{2}$ kurang sesuai untuk evaluasi akurasi, simulator sangat berguna untuk evaluasi repeatability. Dengan begitu, diharapkan dapat membantu proses produksi dan evaluasi pulse oximeter, sehingga dapat meningkatkan jumlah instrumen kesehatan lokal yang teruji dengan baik, khususnya pulse oximeter. Dengan harga yang terjangkau, diharapkan fasilitas pelayanan kesehatan dapat memiiliki simulator parameter vital kesehatan dan melakukan evaluasi mandiri instrumennya secara berkala, sehingga hasil pengukuran parameter vital pasien lebih terjamin.

\section{METODOLOGI}

\subsection{Data Referensi Karakteristik Simulasi}

Data referensi diperoleh dari simulator komersial yang terdapat di Pusat Penelitian Sistem Mutu dan Teknologi Pengujian (P2SMTP) - LIPI. Dari keterangan petugas di laboratorium di P2SMTP, alat tersebut hanya dapat digunakan jika sumber cahaya terdapat dua jenis, inframerah dan merah. Jika hanya salah satu, simulator tidak dapat diaktifkan untuk menyimulasikan tingkat saturasi oksigen. Dari informasi tersebut dapat disimpulkan bahwa aktivasi LED simulator disesuaikan dengan timing LED dari instrumen yang diuji. Metode pengambilan data referensi dideskripsikan oleh blok diagram pada Gambar 4. 


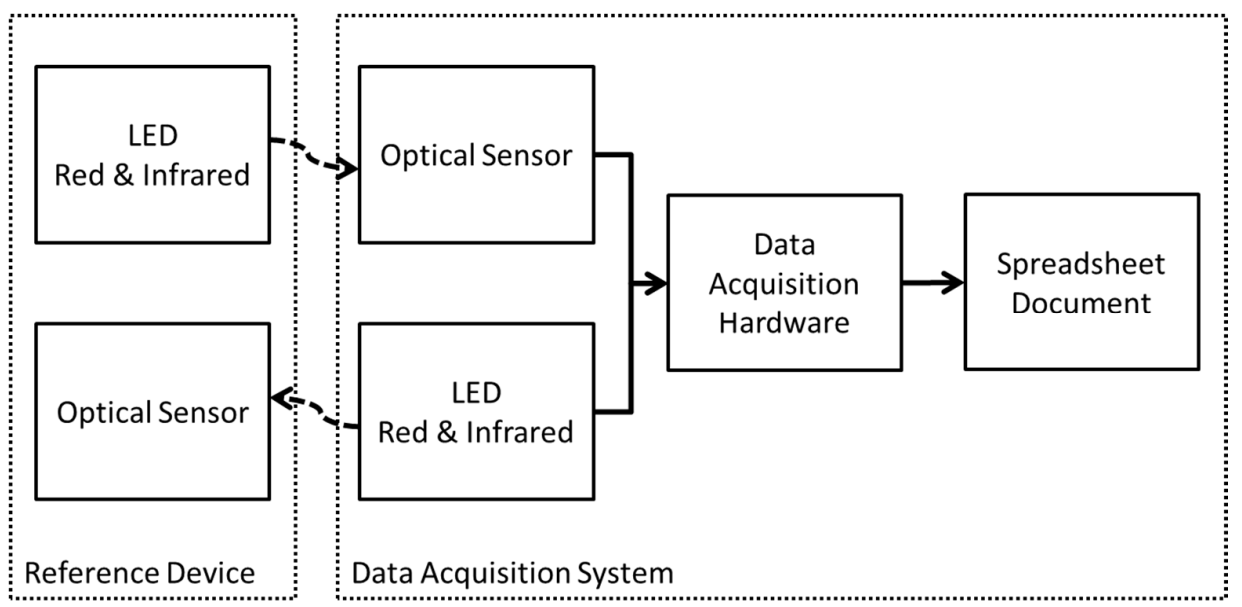

\section{Gambar 3. Blok Diagram Pengambilan Data Referensi}

Sistem data akuisisi direalisasikan menggunakan sensor pulse oximeter yang dimodifikasi, sepeerti yang ditunjukkan pada Gambar 5. Modifikasi yang dilakukan yaitu penambahan sensor cahaya OPT101 untuk mendeteksi perubahan cahaya dari alat referensi. Penambahan sensor cahaya dilakukan untuk mempermudah pengambilan data, karena data dari sensor cahaya bawaan pada sensor pulse oximeter tidak dapat diperoleh perbedaan yang signifikan. Dengan begitu terdapat dua sensor cahaya pada set sensor pulse oximeter tersebut. Sensor tambahan terletak di sebelah kanan pada Gambar 5.

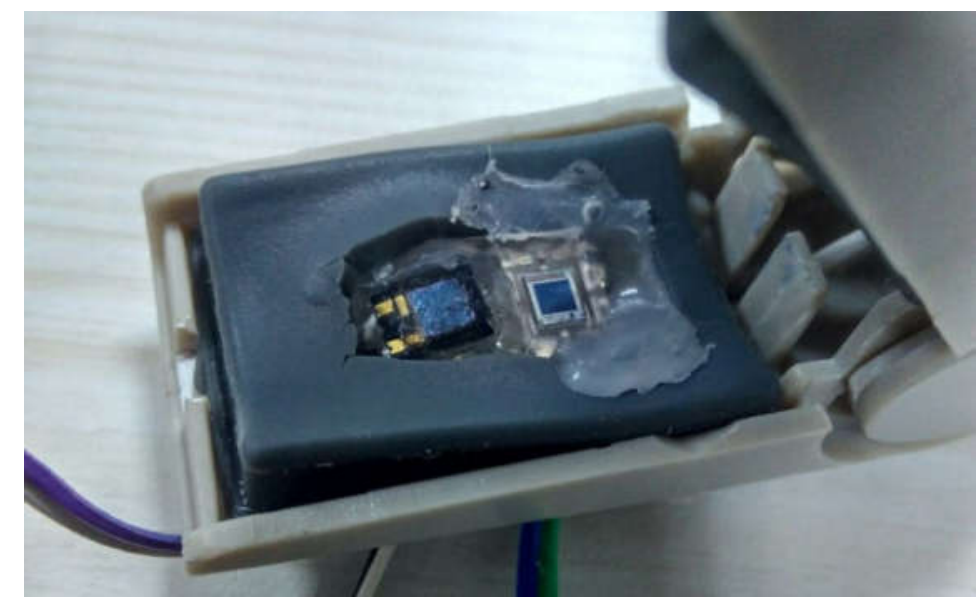

\section{Gambar 4. Penambahan Sensor Cahaya pada Sensor Pulse Oximetry}

Data mentah simulasi saturasi oksigen yang diterima oleh sensor cahaya ditunjukkan oleh Gambar 6, yang diambil secara bersamaan dengan aktivasi LED dari instrumen yang diuji. Garis berwarna biru merepresentasikan output sensor cahaya yang menerima cahaya dari LED simulator, sedangkan garis berwarna hijau merepresentasikan aktivasi LED instrumen yang sedang diuji. LED merah aktif pada sinyal positif, LED inframerah aktif pada sinyal negatif. Dari gambar tersebut terlihat bahwa aktivasi LED simulator, diindikasikan oleh output dari sensor cahaya, hampir serentak dengan aktivasi LED instrumen yang diuji. 


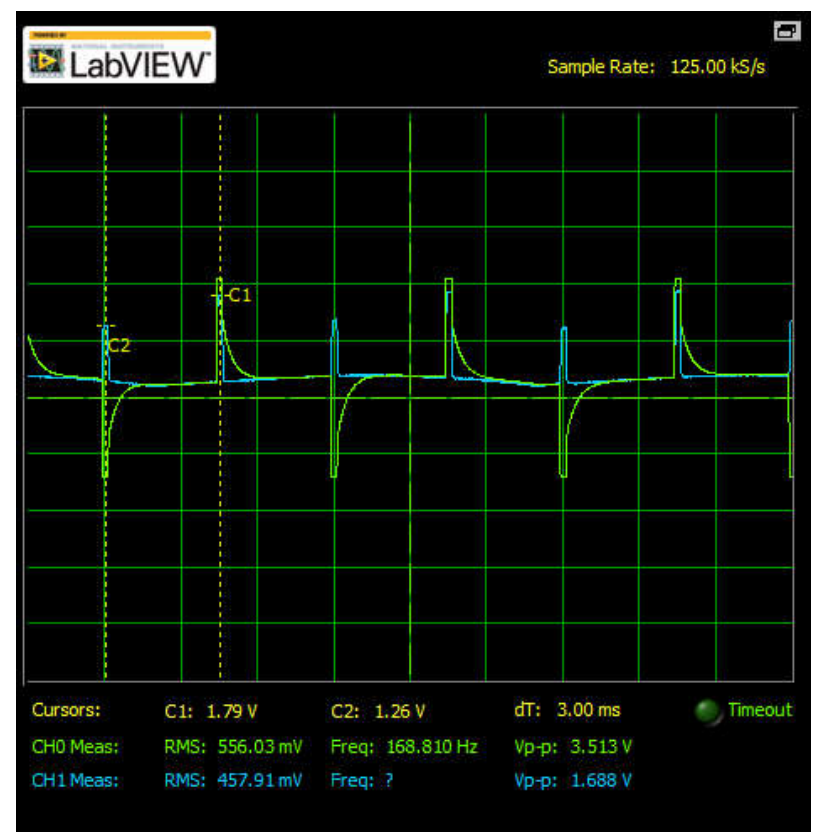

\section{Gambar 5. Data Mentah Simulasi Saturasi Oksigen}

Pada data mentah yang diperlihatkan Gambar 6, terdapat derau 50 Hertz yang disebabkan oleh tegangan jala-jala. Derau tersebut dieliminasi pada proses pengolahan data, sekaligus dipisahkan output cahaya terhadap cahaya merah dan inframerah. Salah satu contoh data yang telah diolah diperlihatkan pada Gambar 7.

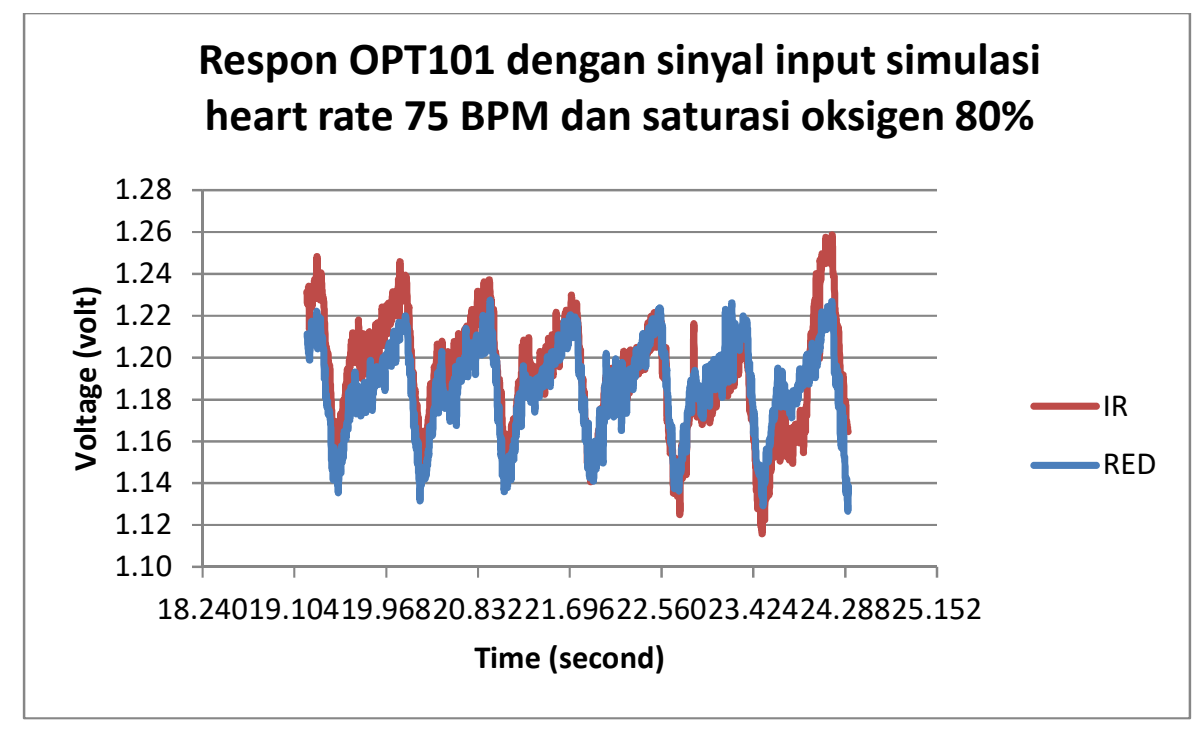

Gambar 6. Data Referensi yang Telah Diolah

Data yang telah diolah perlu dianalisis untuk mengetahui perbandingan tingkat terang cahaya merah dan inframerah pada beberapa nilai saturasi oksigen, dan jarak antar pulsa yang berkaitan dengan detak jantung. Tabel 2 menunjukkan hasil analisis karakteristik sinyal simulasi untuk beberapa nilai saturasi oksigen dan detak jantung. 
Tabel 1. Karakteristik Data Referensi

\begin{tabular}{|c|c|c|c|c|c|c|c|}
\hline \multirow[t]{2}{*}{$\begin{array}{l}\text { Saturasi } \\
\text { Oksigen }\end{array}$} & \multicolumn{2}{|c|}{$\begin{array}{c}\text { Vout Red } \\
\text { (Volt) }\end{array}$} & \multicolumn{2}{|c|}{$\begin{array}{c}\text { Vout Infrared } \\
\text { (Volt) }\end{array}$} & \multirow[t]{2}{*}{ R-rate } & \multirow{2}{*}{$\begin{array}{l}\text { Heart } \\
\text { Rate } \\
\text { (BPM) }\end{array}$} & \multirow{2}{*}{\begin{tabular}{|c|} 
Pulse \\
time \\
(milisecond)
\end{tabular}} \\
\hline & Puncak & Lembah & Puncak & Lembah & & & \\
\hline $80 \%$ & 1.222215 & 1.134113 & 1.232509 & 1.141506 & 1.025589 & 75 & 800.00 \\
\hline $86 \%$ & 1.221718 & 1.142849 & 1.237062 & 1.144483 & 1.172121 & 80 & 750.00 \\
\hline $90 \%$ & 1.222984 & 1.150942 & 1.236219 & 1.145591 & 1.255670 & 85 & 705.88 \\
\hline $96 \%$ & 1.221636 & 1.161037 & 1.233427 & 1.140503 & 1.542519 & 90 & 666.67 \\
\hline $100 \%$ & 1.223987 & 1.173019 & 1.244048 & 1.157389 & 1.773742 & 95 & 631.58 \\
\hline
\end{tabular}

\subsection{Sistem Simulator}

Dari karakteristik simulator referensi dan data referensi, desain awal sistem dapat dibuat. Gambar 8 memperlihatkan blok diagram sistem yang menunjukkan desain hardware dan konektivitas antar komponen. Sebagai sensor cahaya digunakan photodiode tipe OPT101 yang telah terintegrasi dengan transimpedance amplifier. Sebagai controller digunakan Arduino UNO. LED Driver dibuat customized berbasis Digital to Analog Converter tipe MCP4822 yang memiliki dua kanal keluaran analog. Untuk sumber cahaya merah dan inframerah, digunakan $\angle E D$ combo yang diambil dari alat pulse oximeter murah yang ada di pasaran. Sebagai display dan input setting control masih menggunakan terminal komunikasi serial dengan antarmuka komputer.

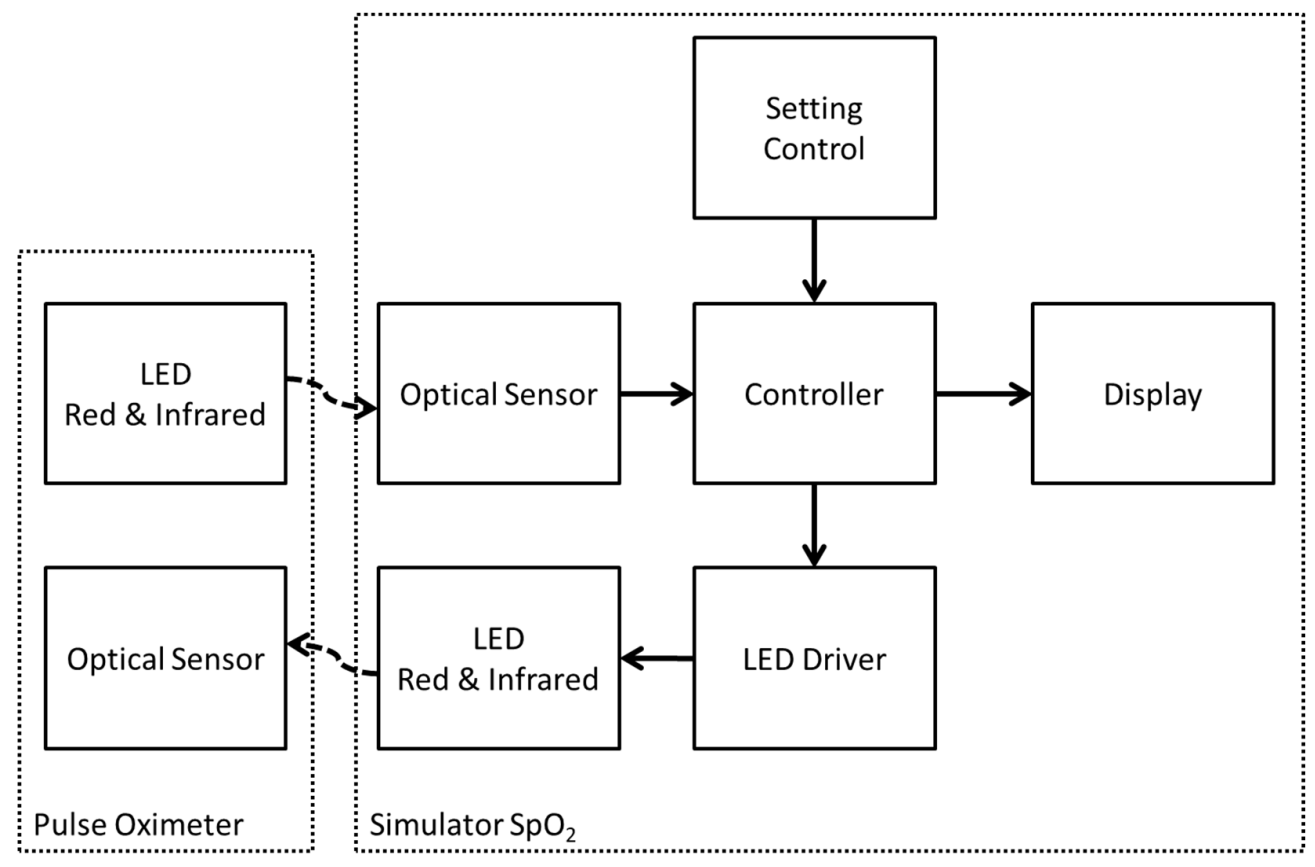

Gambar 7. Blok Diagram Sistem 
Prinsip kerja sistem dijelaskan melalui diagram alir yang ditunjukkan oleh Gambar 9, Gambar 10, Gambar 11, dan Gambar 12.

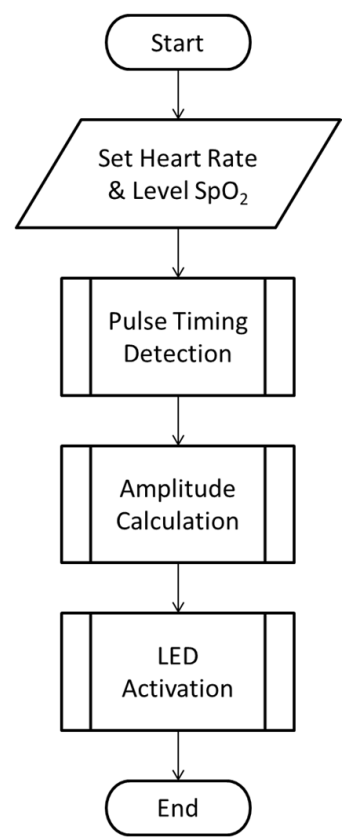

Gambar 8. Diagram Alir Utama Sistem

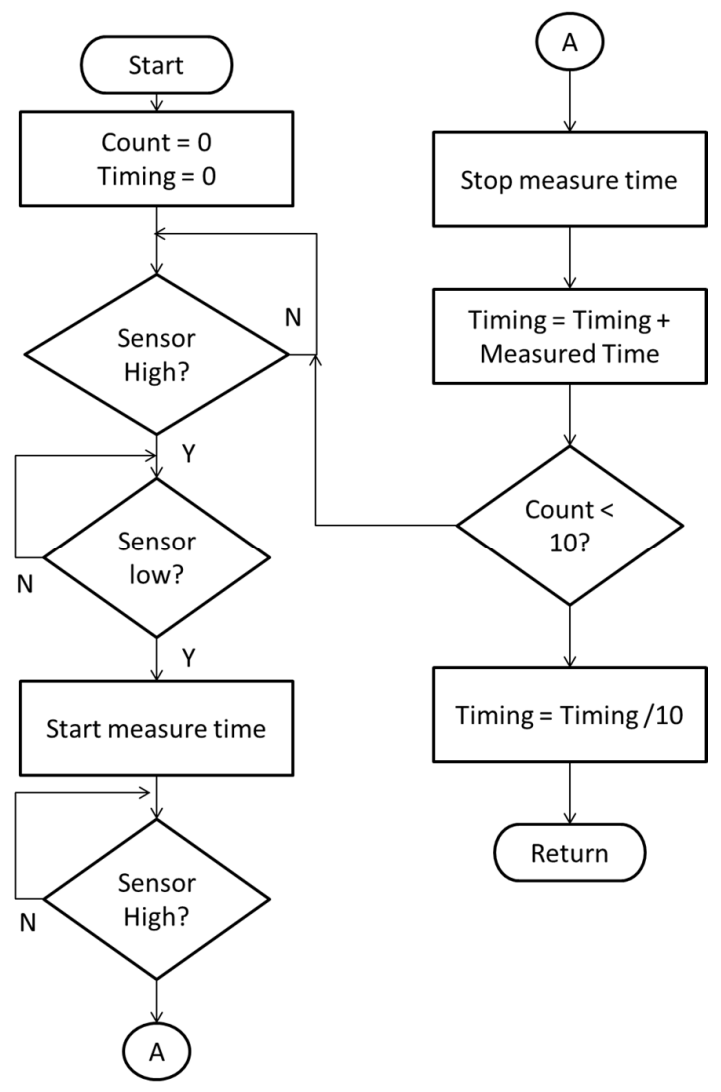

Gambar 9. Diagram Alir Pulse Timing Detection 


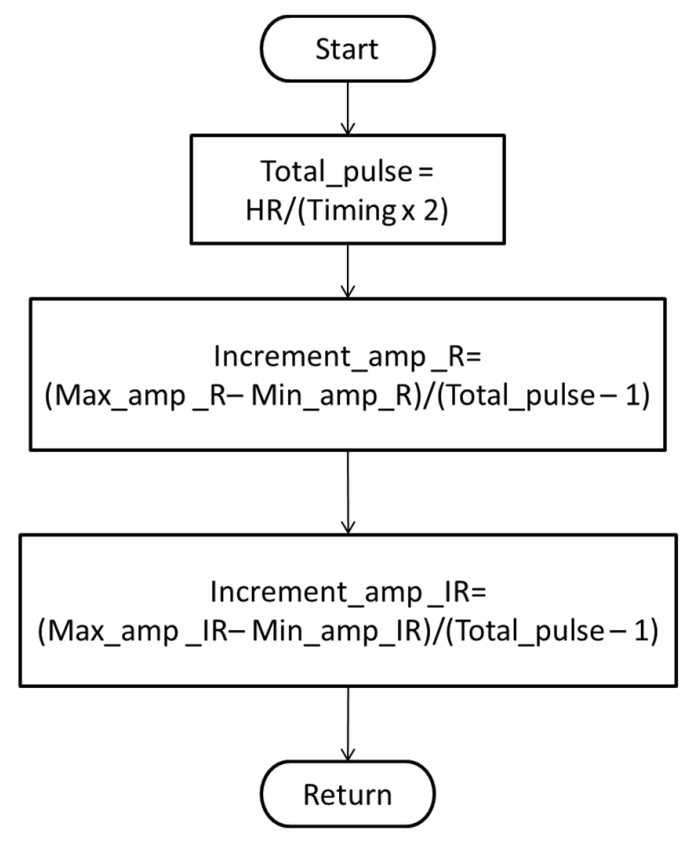

Gambar 10. Diagram Alir Amplitude Calculation

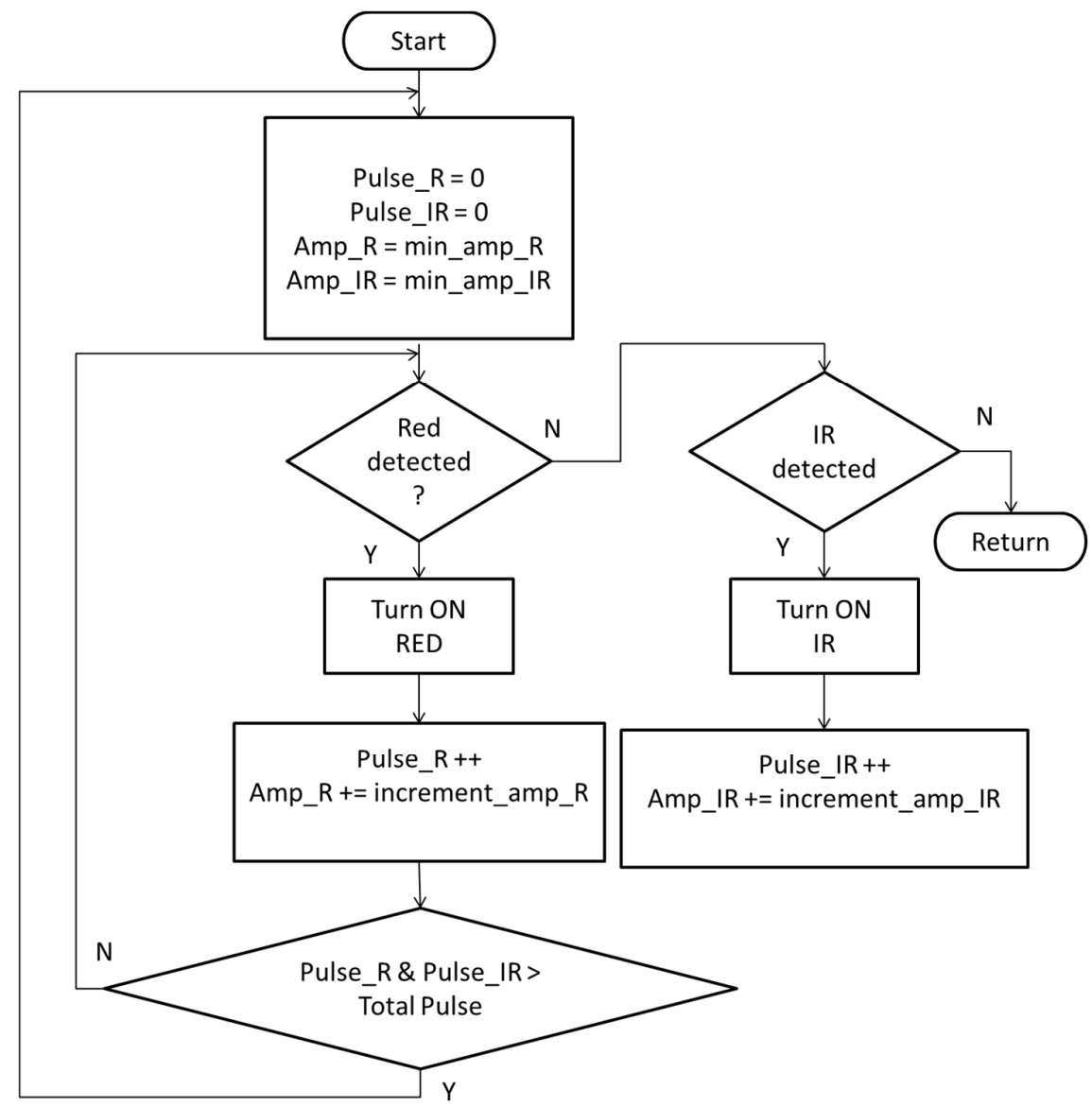

Gambar 11. Diagram Alir LED Activation 


\section{HASIL DAN PEMBAHASAN}

\subsection{Realisasi Sistem}

Sesuai dengan desain hardware yang dideskripsikan oleh blok diagram sistem, hardware telah direalisasi menggunakan PCB matrix untuk jari artifisial. Jari artifisial terdiri dari sensor cahaya (OPT101) dan LED combo, merah dan inframerah. DAC MCP4822 sebagai LED Driver masih direalisasikan pada project board. Kedua modul tersebut, dihubungkan dengan kontroler (Arduino Mega ADK) menggunakan kabel jumper. Gambar 13 memperlihatkan modul jari artifisial dalam keadaan terpisah antara sensor cahaya dan LED combo. Gambar 14 memperlihatkan modul LED Driver yang terhubung dengan kontroler. Tabel 3 menunjukkan daftar perangkat keras beserta kisaran harganya.

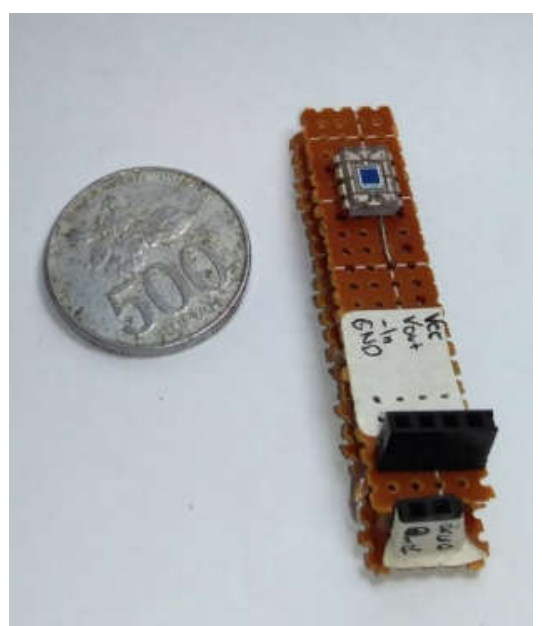

(a)

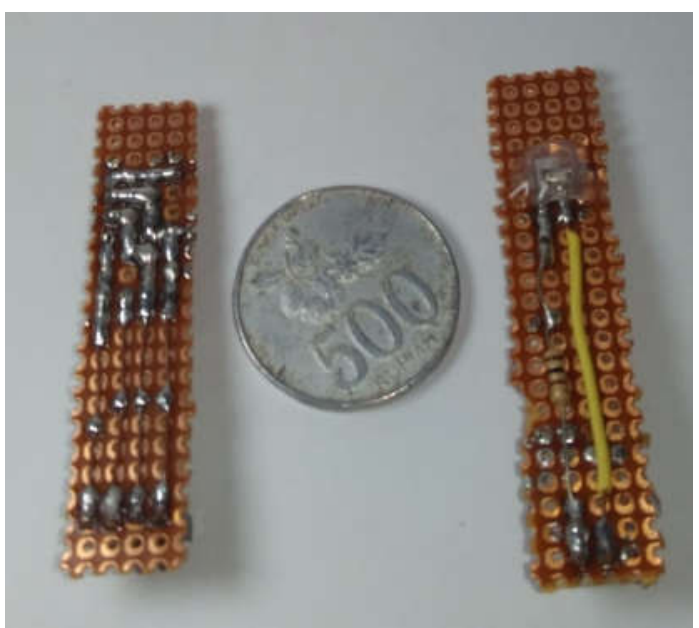

(b)

Gambar 12. Modul Jari Artifisial. (a) Terintegrasi (b) Terpisah Tampak Belakang

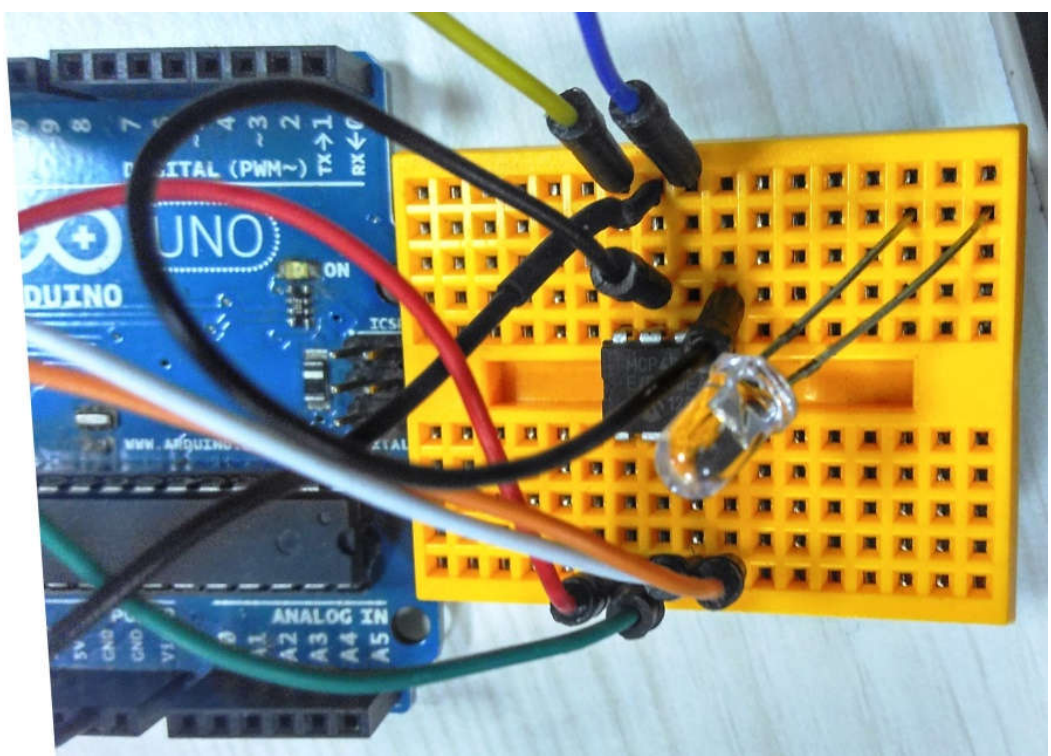

Gambar 13. Modul LED Driver 
Tabel 2. Daftar Perangkat Keras yang Digunakan

\begin{tabular}{|l|r|l|}
\hline Jenis & Harga (rupiah) & Keterangan \\
\hline Arduino Uno & 450.000 & Kontroler \\
\hline LED combo R-IR & 200.000 & $\begin{array}{l}\text { Menggunakan LED dari } \\
\text { pulse oximeter murah }\end{array}$ \\
\hline DAC MCP4822 & 150.000 & LED driver \\
\hline OPT101 & 150.000 & Sensor cahaya \\
\hline Pelengkap & 50.000 & Kabel, PCB \\
\hline TOTAL & $\mathbf{1 . 0 0 0 . 0 0 0}$ & \\
\hline
\end{tabular}

Gambar 15 menunjukkan hasil pengukuran output sensor OPT101 pada jari artifisial, ditunjukkan oleh garis hijau, saat mendeteksi cahaya merah dan inframerah dari sensor pulse oximeter. Garis biru menunjukkan aktivasi LED merah dan inframerah, dengan cahaya inframerah aktif pada polaritas positif. Hasil tersebut menunjukkan bahwa output sensor memiliki amplitudo lebih tinggi saat mendeteksi cahaya inframerah. Hasil tersebut diperoleh dengan menempatkan sensor OPT101 agak menjauh dari LED sensor pulse oximeter, tidak tepat di depannya. Posisi sensor OPT101 cukup sensitif untuk bisa menghasilkan hasil yang serupa, jika terlalu dekat dengan LED sensor pulse oximeter tegangan outputnya tidak jauh berbeda untuk sinar merah dan inframerah.

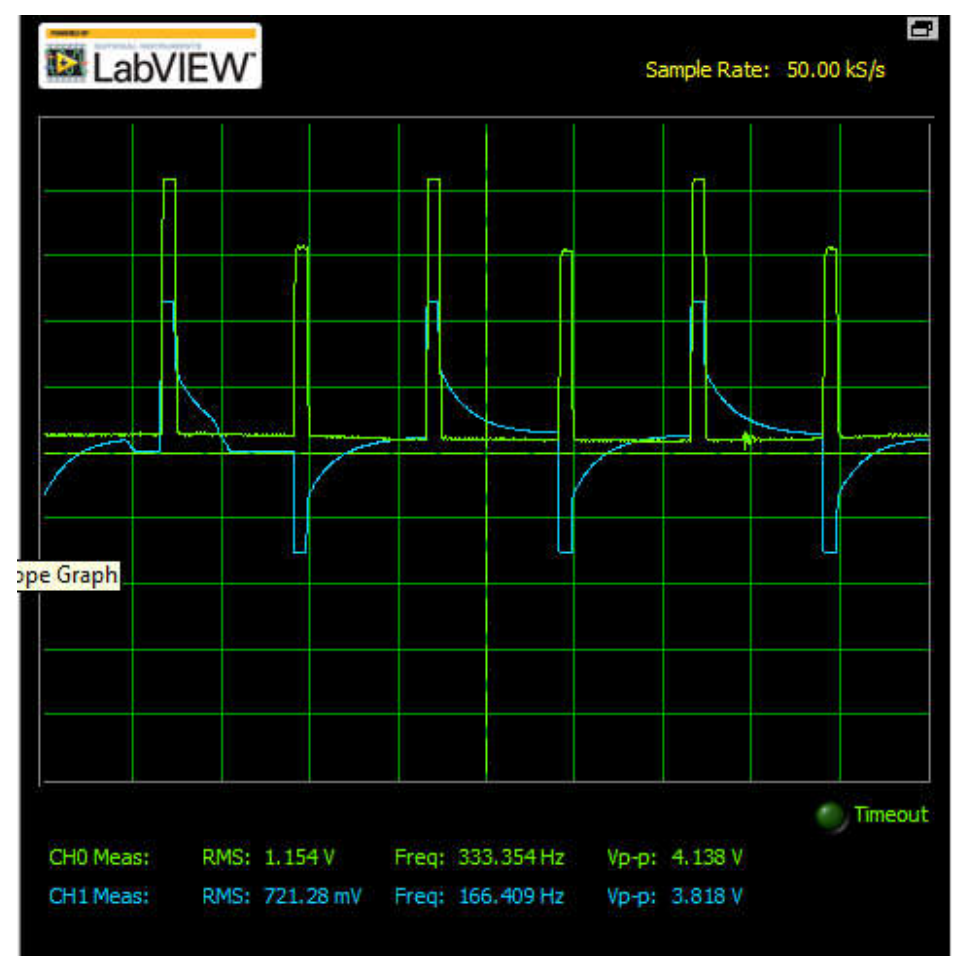

\section{Gambar 14. Pendeteksian Cahaya Merah dan Inframerah}

Karena DAC yang digunakan memiliki resolusi 12 bit, maka rentang nilai masukan digital adalah 0-4095, dengan rentang tegangan keluaran adalah 0-2 volt atau 0-4 volt tergantung pengaturan penguatan pada program untuk DAC. Setelah dilakukan pengujian awal, $L E D$ Driver mampu mengaktifkan kedua LED secara bergantian dengan tegangan berbeda-beda. Gambar 16 menunjukkan grafik output sensor OPT101 pada sistem akuisisi data terhadap cahaya LED merah pada jari artifisial yang diaktifkan oleh LED Driver. Sedangkan Gambar 17 
menunjukkan grafik output sensor OPT101 pada sistem akuisisi data terhadap cahaya LED infra merah pada jari artifisial. Di luar rentang input digital pada kedua grafik tersebut, output OPT101 tidak ada perubahan signifikan. Kedua grafik tersebut dilengkapi dengan persamaan hasil pencocokan kurva.

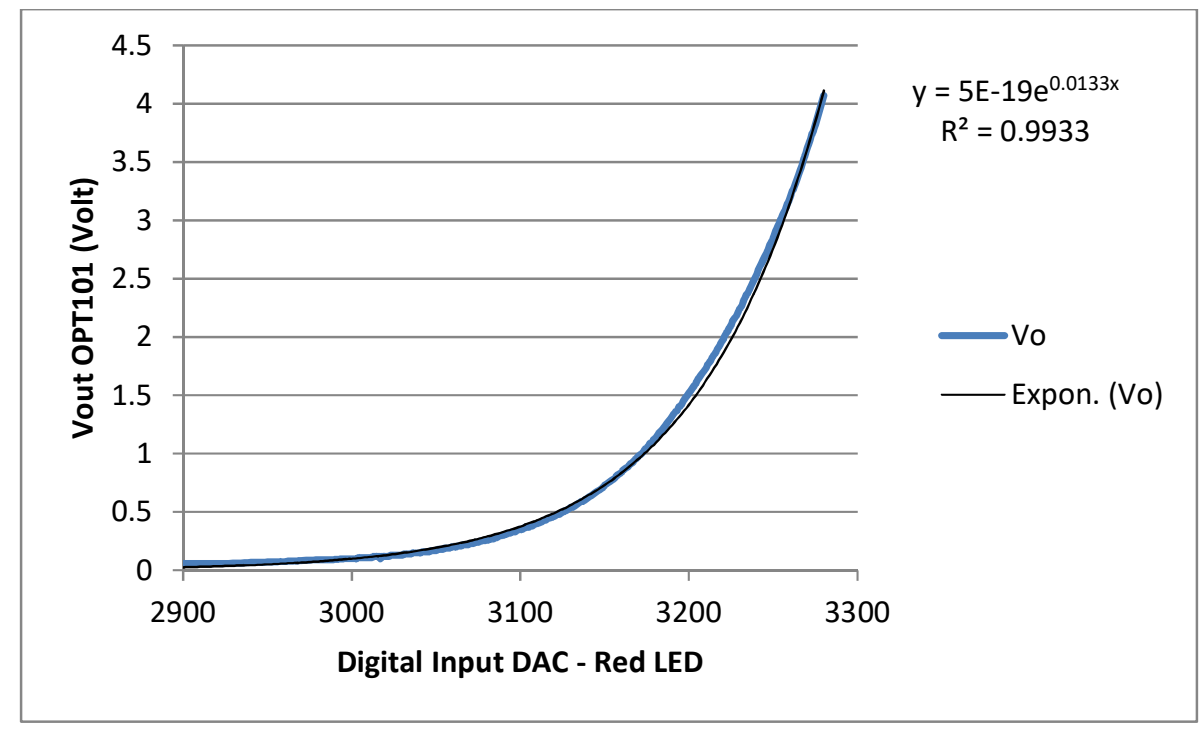

Gambar 15. Grafik Output OPT101 terhadap Input Digital Cahaya Merah

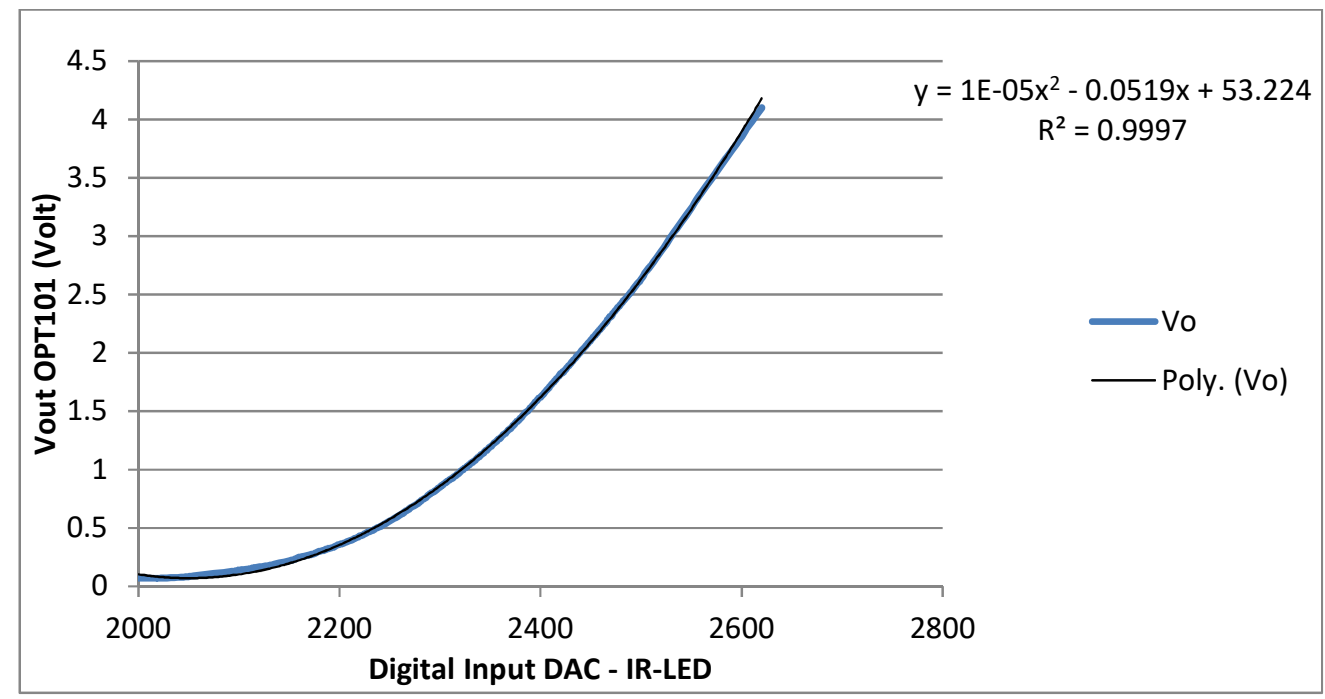

\section{Gambar 16. Grafik Output OPT101 terhadap Input Digital Cahaya Inframerah}

Hasil karakteristik sensor pada cahaya merah dan inframerah dengan intensitas berbedabeda tersebut kemudian digunakan untuk menyimulasikan kadar saturasi oksigen. Simulasi dilakukan dengan mengatur tegangan LED merah dan inframerah untuk berubah secara teratur mencapai titik tertentu sesuai $R$-rate dan laju denyut yang diinginkan. $R$-rate menentukan perbandingan amplitudo penerimaan cahaya merah dan infra merah oleh sensor, laju denyut menentukan total durasi perubahan amplitudo tersebut. Kedua nilai tersebut mengacu pada data yang ditunjukkan oleh Tabel 2. 
Untuk pembuktian konsep dilakukan pengujian simulasi untuk kadar saturasi oksigen $80 \%$ dan laju denyut 80 denyut per menit. Output sensor cahaya tambahan pada sensor pulse oximeter ditunjukkan pada Gambar 18. Terlihat bahwa bentuknya sudah cukup mirip dengan denyut yang ditampilkan pada layar pulse oximeter ketika mengukur saturasi oksigen, tetapi durasinya belum sesuai dengan yang diinginkan. Durasi yang diinginkan adalah 750 milidetik, tetapi durasi simulasi menghasilkan durasi 690 milidetik yang secara teori akan menghasilkan laju denyut 87 denyut per menit. Kemiringan yang cukup baik pada grafik juga menunjukkan respon sensor terhadap cahaya merah dan inframerah hampir sama, sesuai dengan $R$-rate mendekati 1.

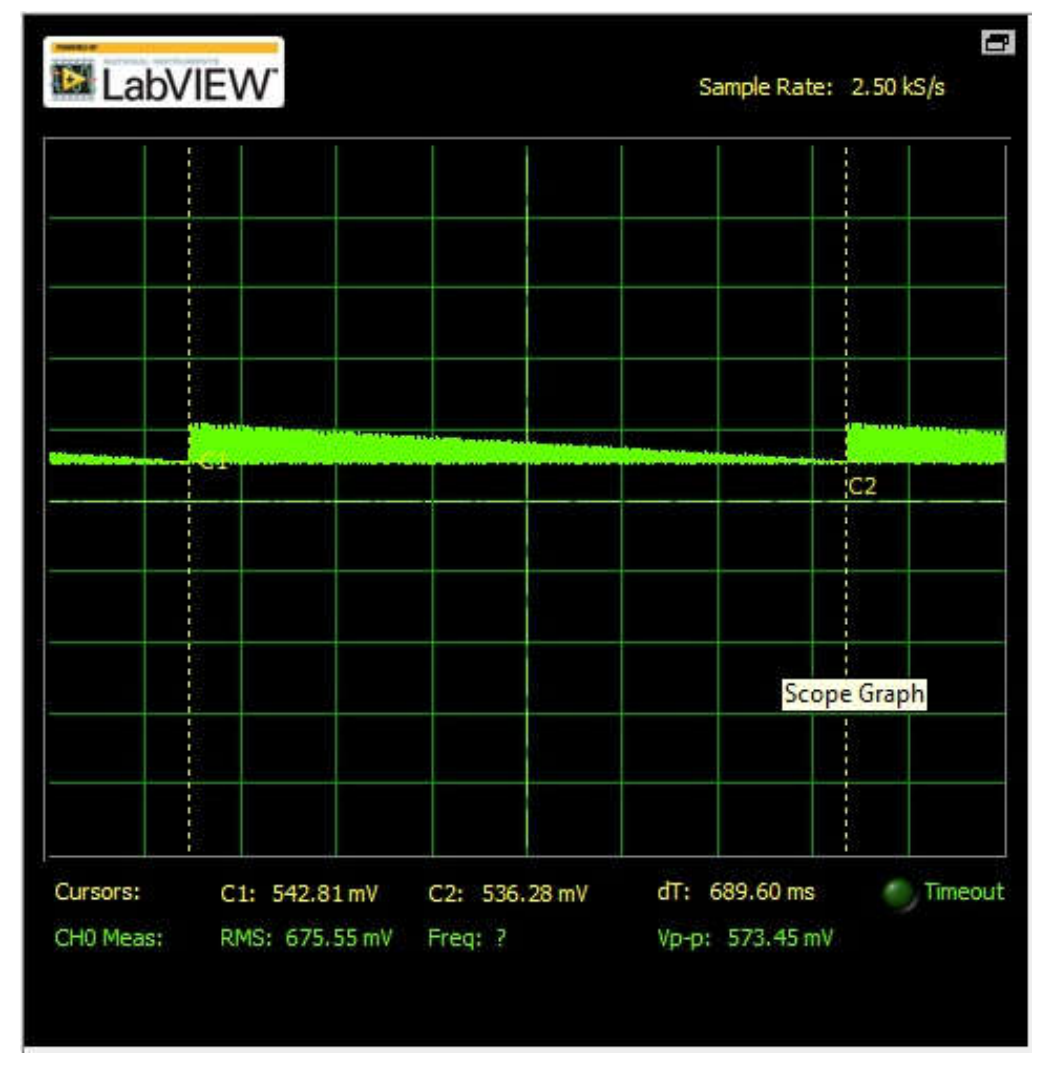

\section{Gambar 17. Simulasi Kadar Saturasi Oksigen $80 \%$ dan Laju Denyut 80 Denyut per Menit}

Tetapi hasil simulasi tersebut belum menunjukkan hasil yang sempurna ketika diuji pada pulse oximeter referensi. Pulse oximeter tersebut mampu mendeteksi adanya denyut, tetapi grafik yang ditampilkan tidak beraturan dan nilai kadar saturasi oksigen tidak sesuai yang diinginkan. Kadar saturasi oksigen hasil simulasi tidak stabil pada rentang 82-89\%, dengan target $80 \%$. Laju denyut pun tidak sesuai dengan data yang diperoleh pada osiloskop, yaitu 83-85 denyut per menit. Dengan begitu dapat dikatakan galat maksimal mencapai $11.25 \%$ untuk kadar saturasi oksigen, dan mencapai $6.25 \%$ untuk laju denyut. Karena nilai galat yang cukup besar dan hasil yang fluktuatif, percobaan dengan nilai kadar saturasi oksigen dan laju denyut lain dirasa tidak diperlukan, karena tidak akan memberikan perbaikan hasil yang signifikan. Salah satu cuplikan hasil pengukuran oleh pulse oximeter ditunjukkan oleh Gambar 19. 


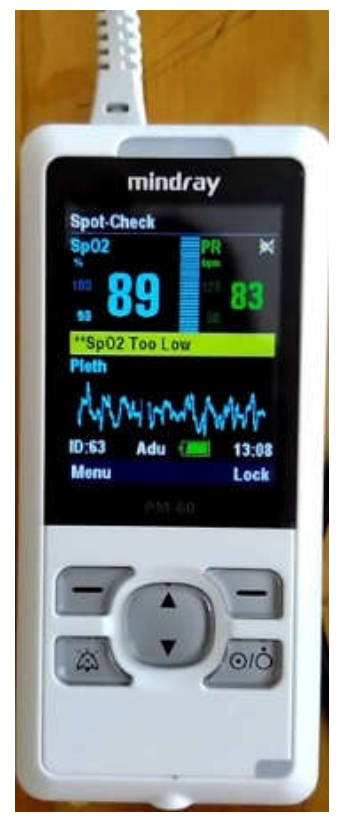

\section{Gambar 18. Cuplikan Hasil Pengukuran Pulse Oximeter}

\section{KESIMPULAN}

Purwarupa berhasil direalisasikan, dengan biaya untuk membuat perangkat keras dari purwarupa ini mencapai sekitar satu juta rupiah. Masih jauh lebih murah jika dibandingkan dengan harga jual simulator yang ada di pasaran.

Untuk pembuktian konsep, purwarupa telah diuji untuk kadar saturasi oksigen $80 \%$ dengan laju denyut 80 denyut per menit. Hasilnya simulasi masih belum stabil, tapi sudah dapat dideteksi oleh pulse oximeter. Galat maksimal dari simulasi tersebut mencapai $11.25 \%$ untuk kadar saturasi oksigen, dan mencapai $6.25 \%$ untuk laju denyut. Hasil simulasi juga masih fluktuatif, sehingga untuk evaluasi repeatability pun masih tidak dapat digunakan.

Walaupun pada penelitian ini hasil simulasi yang terbaca oleh pulse oximeter referensi belum begitu baik. Konsep simulasi kadar saturasi oksigen yang diajukan dengan menggunakan hardware yang digunakan pada studi ini, terbukti dapat diaplikasikan untuk menyimulasikan kadar saturasi oksigen secara optikal.

Perbaikan masih perlu dilakukan dari sisi perangkat lunak dan metode pengambilan data referensi agar didapatkan hasil yang lebih baik pada pembacaan pulse oximeter, sehingga dapat digunakan sesuai dengan peruntukan untuk mengevaluasi karakteristik statis dari pulse oximeter.

Langkah selanjutnya yang perlu dilakukan untuk menyempurnakan hasil studi ini adalah pengambilan data referensi ulang dengan menggunakan sistem akuisisi data yang lebih baik dan perbaikan perangkat lunak mengacu pada data terbaru. Kemungkinan penambahan sensor cahaya pada sensor bawaan, menyebabkan pembacaan salah satu sensor tidak sempurna. Selain itu perlu dilihat lebih detail lagi karakteristik pulse oximeter ketika ada jari dan tanpa jari. Bisa jadi ada perbedaan, sehingga seluruh pengambilan data referensi perlu diklasifikasi. 


\section{UCAPAN TERIMA KASIH}

Terima kasih untuk Kementerian Riset dan Pendidikan Tinggi Republik Indonesia untuk pendanaan studi ini melalui skema Penelitian Dosen Pemula, dan kepada tim Laboratorium Teknologi Pengujian Peralatan Kesehatan, Pusat Penelitian Sistem Mutu dan Teknologi Pengujian - Lembaga Ilmu Pengetahuan Indonesia (P2SMTP - LIPI) untuk izin dan bantuannya dalam proses pengambilan data.

\section{DAFTAR RUJUKAN}

Hadiyoso, S., Nursanto, N., Rizal, A. 2015. Implementasi Regulator Oksigen Otomatis berdasarkan Tingkat Pernapasan Menggunakan Logika Fuzzy. Jurnal ELKOMIKA, 3(2), 52-63.

Konica Minolta Sensing, Inc. 2006. How to Read Spo - Basic understanding of the pulse oximeter. (http://windward.hawaii.edu diakses 22 April 2016)

McMahon, D. J. 2013. There's no such thing as a $\mathrm{SpO}_{2}$ simulator. Fluke Biomedical White Paper.

Merrick, E.B., Peter Haas. 1994. Simulation for pulse oximeter. United States Patent 5348005.

Philips Medical System. 2002. Understanding Pulse Oximetry $\mathrm{SpO}_{2}$ Concepts. (http://incenter.medical.philips.com diakses 22 April 2016).

Stubán, N., Masatsugu, N. 2008. Non-invasive calibration method for pulse oximeters. Periodica Polytechnica Electrical Engineering, 52(1-2), 91-94.

Withings. What does $\mathrm{SpO}_{2}$ mean? What is a normal $\mathrm{SpO}_{2}$ level? (https://withings.zendesk.com diakses 22 April 2016)

Zhang, P., Hong, B., Chen, J. Design of Calibration Device for Pulse oximeter Simulator. 2013. Chinese Journal of Biomedical Engineering (English Edition), 22(4), 161-168. 